\title{
CORPORATE LAND DEALS, DISPOSSESSION AND THE FUTURE OF FARMING
}

Ben White, International Institute of Social Studies (ISS), The Hague

\section{Introduction $^{1}$}

Forty-five years ago the Polish economist Michal Kalecki, after visiting Egypt, Indonesia and some other postcolonial countries, noted the survival and apparent resilience of what he called the "intermediate classes" in agriculture and other sectors (by which he meant smalland medium-scale farms and other enterprises). He also raised the question whether, at some future moment, we would see their disappearance in final submission to the interests of big business (Kalecki 1967). Observing the current wave of large-scale, state-supported corporate acquisitions of contested lands and common lands today - in Africa, Asia, Latin America, and the former Soviet Union - one wonders whether Kalecki's moment has finally arrived.

In the last few years the useful fact-finding work and publicity on these land deals, both by mainstream international agencies and more critical NGOs has established beyond doubt that large-scale corporate land acquisitions and the accompanying dispossession of local people are occurring on an unprecedented scale (the studies and estimates are critically summarized by Cotula 2012). It sometimes appears that different agencies are competing to produce the highest estimates of the total area subjected to land 'grabs' - 80 million hectares according the International Land Coalition (Anseeuw at al. 2012), 227 million hectares according to Oxfam (2011) - but as land deals are typically shrouded in secrecy, nobody really knows how much land is being acquired. All agree however that the greatest concentration of land deals - certainly more than 60 percent- is in sub-Saharan Africa (Cotula 2012: 650-656).

The academic world has been quick to respond to these developments. There is now quite an industry of academic, field research-based 'land-grab studies' underway, both by established scholars and also particularly by graduate students, and we will see an explosion of interesting dissertations, conferences, special issues of journals and so on in the coming years. When the Land Deals Politics Initiative called for papers for for the International Conference on Global Land Grabbing held in April 2011 at the Institute of Development Studies at the University of Sussex, and later for the 'International Land Grabbing II' conference at Cornell University in October 2012, in each case more than 400 abstracts were submitted, nearly all of them based on original field research.

As researchers we aim to go beyond fact-finding or general expressions of concern, and there are many kinds of questions to which the work of analysing and theorising foreign land claims and acquisitions might respond. First, why is it happening? And more specifically: why is it happening now? Second, how important is its transnational character?

\footnotetext{
${ }^{1}$ This chapter is a revised version of the address "Who will own the countryside? Corporate land deals and the future of farming" presented at the NVAS International Conference Africa for sale: analysing and theorising foreign land claims and acquisitions, University of Groningen, 28-29 October 2010. Some parts are drawn from (White 2011).
} 
From whose point of view? Then, how does a corporate (transnational) land acquisition work? How is production organised in the newly enclosed lands? Who gains, who loses? What are the forms of local response (which may include both resisting and welcoming the presence of new investors) and how is resistance organised? What has been the international policy response? What is the role of states in welcoming or blocking foreign investment, and in shaping these processes more generally? And finally: if 'land grabbing' continues on a large scale, what are the implications for the future of global farming systems? The following sections touch briefly on each of these issues.

\section{Why Do Land ‘Grabs’ Happen?}

The current land rush, and the discourses of states, corporate investors and international agencies that comes with it, is full of contradictions. On the one hand, most countries in the global south report declining farm sizes, land shortage and often food insecurity, while states and corporations justify the acquisition of large areas of land by claiming the availability of huge areas of "empty" or "unused" land in the same countries. These land deals are usually based on corporate promises to develop modern, industrial forms of agricultural production for food, feed, fuel, or fibre for export. Research has long ago shown, however, that such industrial (capital- and energy-intensive) forms of agriculture are unsustainable, and will accelerate global warming rather than slow it down (for example, many studies cited in IAASTD 2009). Meanwhile key international agencies, quite aware of this research and having themselves sponsored and published some of it, seem to have accepted that this form of agriculture is going to be the main motor of agricultural growth in the coming years.

The World Bank's policy report Rising global interest in farmland - can it yield sustainable and equitable benefits? (2010) embodies these contradictions. It includes several case studies commissioned by the Bank (including as African cases the Democratic Republic of Congo, Liberia, Mozambique, Tanzania, and Zambia). These studies document clearly that land investments are not fulfilling their promise of employment creation for local people, they are environmentally destructive, they disadvantage women, they ignore the proper legal procedures for acquiring land, and in many cases forcibly displace large numbers of people (Scoones 2010). But the same report proposes that any problems of governance, illegality and environmental destruction be prevented by the acceptance and implementation of a voluntary 'code of conduct' (further discussed below), after which corporate capital will behave more responsibly.

A number of authors have attempted to explain why the rapid increase in global land acquisitions is happening now. Annelies Zoomers (2010, see also this volume) has correctly argued that there are many different processes behind the current land rush, of which foreign investment in 'offshore farming' - which includes food, livestock feed and fuel feedstock development, makes up only one of several "drivers". Even within this one category of offshore farming, the reasons behind such foreign investments can differ widely. For example, East Asian or Gulf-state corporations, often set up by governments to make investments in food or fuel production in distant countries, may be driven by concerns to ensure food and fuel security at home in an era of recurrent shortages and rising commodity prices. Conversely, when a hedge fund (or my American pension fund) makes similar 
investments, investors are not at all worried about food scarcities or rising prices; on the contrary, they welcome global scarcity, they live by it and hope it will continue, as speculation over increasing land prices due to scarcity creates an opportunity for capital accumulation. Farm land has effectively become a relatively safe and attractive investment in today's turbulent global economy.

But besides asking why the corporate land rush is happening now, we could equally ask, why is it only happening now, or why did it not already happen long ago? Isn't this what we should expect in this (post-) neoliberal era of late capitalism? Is it not part of the free marketeers' dream that governments in the global south should follow the example of countries like the United States, the Netherlands or Australia (to name a few) where land markets have always been open to foreign buyers.? The logic of the global market necessarily involves the free mobility of capital, such that markets in land (like markets in everything else) should be laid open to cross-border transactions and buyers. In a world in which every bit of the planet is potentially up for sale, or at least for long-term lease, to whoever wants to buy it, foreign land acquisitions are expected to even out spatial imbalances in the demand for and the supply of land and food. This vision of the benign influence and developmental potential of free markets in land ignores the fact that 'real' markets (whether at the village, regional, national or global level) are not sites where local land users, as willing sellers, meet willing buyers on an equal footing, to the benefit of each, but sites where unequal power is exercised, to the benefit of the more powerful. Indeed in many large land deals, those who cultivate the land are not the ones making the deals, and may not even be consulted about them, because of the state's claim to be the sovereign owner of public or common lands and lands held under customary tenure (Wily 2012; Cotula 2011).

Most regions of the global south have experienced a long history of large-scale land appropriations by both domestic and foreign actors; first by pre-colonial rulers during chronic internal wars and conflicts over territory, then by colonial governments and now, increasingly, by foreign or domestic corporations supported by government. In the early $19^{\text {th }}$ century, outright sale by colonial powers of large tracts of land held in customary tenure was quite common, but this was often prohibited or limited by later colonial legislation such that longer term leases became the norm. In the post-colonial decades, both governments and civil society groups attempted to correct some of these historical distortions by implementing land reforms or other means so as to break up of large private or corporate estates and re-distribute land to smallholders (see for example Warriner 1969, Sobhan 1993, Lipton 2010). This was often done with the support of international agencies, such as the World Bank, which was a major proponent of the dismantling of former colonial concessions in favour of small-holder based agricultural development strategies up to the 1980s. Paradoxically, these policies are now being reversed as governments support the acquisition of great expanses of land by large corporations, both foreign and domestic, usually in the form of long-term concessions or leases rather than outright purchase. Many of these deals, we now know, run on the margins of hundreds or thousands of hectares; and some of the contiguous areas of land designated by states for corporate land deals exceed millions of hectares. The (potentially) enormous scale and speed of expansion of these deals, which may be more rapid than previous agrocommodity booms in colonial or post-colonial history, may mean that they will have correspondingly greater impact. 
We should remember that not all large-scale land deals actually result in anything, and in many cases it is too early to see what their impacts will be. A government-togovernment land deal is often no more than a framework under which concrete deals between agribusiness corporations and local government for the leasing and enclosure of designated areas may or may not emerge. Potentially, however, these deals open the way to a truly wideranging global land reform; paradoxically though, in the case of the global land rush, it is an 'upside-down' land reform, where instead of equitable land redistribution to correct historical distortions, governments take land from the poor and give it (or lease it) back to the rich.

\section{How Important is the Transnational Character of the Global 'Land Grab'?}

Views on the importance of transnationality in large land deals will probably differ widely, depending on the perspective and the level of analysis. We know that both domestic and foreign investors are currently driving the current land rush, often in collaboration with the state (see Adamczewski et al., this volume). In terms of international relations, it goes without saying that international land deals may have wide-ranging implications and may be the cause of significant international tensions between countries (Strauss, this volume). To some actors (including rural or urban-based political movements with strong nationalist sentiments) it may be particularly important to know whether the companies leasing out land for agro-industrial production of export crops are foreign or domestically operated - or (as is probably most common) a mixture of both. To local populations and farmers, however, the foreign or domestic origins of investment capital, ownership of the crops to be grown and destination of those crops -- where they will eventually be sold as fuel, food, cosmetics, or other final uses - is often unknown and potentially irrelevant. Even if these facts are known by local people (which is often not the case), other issues appear to be of more interest, such as the forms in which the land they use is appropriated (or 'processes of dispossession', see Sapignoli and Hitchcock, this volume), and the ways in which they are excluded or incorporated, sometimes as producers, in global commodity chains (Hall 2011); if contracted by the company, many local people find themselves producing crops for export to faraway places on land which they believed to be theirs, and which used to be the source of their own subsistence and sense of identity (see chapters by Buchalik and Postel, this volume).

Certainly domestic corporations, with their links to people in high places, can be just as ruthless as foreign investors and probably less subject to critical scrutiny by international watchdog organisations. This raises the question of whether agrarian capitalism based on foreign land claims and acquisitions is in any way essentially different from other forms of capitalist agrarian monocrop production, and in turn whether the transitions involved (if any) require new tools of analysis (Adamczewski et al., this volume).

\section{How Does a $21^{\text {st }}$-Century 'Land Grab’ Actually Work?}

While the media often focus on the role of foreign governments concerned with safeguarding supplies of agricultural products and raw materials, the actual "grabbing” of land - by which we mean the dispossession and exclusion of local people due to the enclosure of territory for 
sale or lease to a corporate investor - is commonly done by local governments, working together with investor corporations, and local elites.

In nearly all cases, the land appropriated in this way is the subject of contestation. In many countries, the planned expansion of corporate farming is based in the large areas of land which are not (yet) covered by the laws governing private property relations but have the status of "public" or "state” lands (Adamczewski et al., this volume). While these lands provide livelihoods to millions of cultivators and forest users under a wide variety of unofficial, semi-official or "customary", individual, or collective tenurial relationships, states claim sovereign ownership of the same land. The informal and insecure tenure under which many cultivators and forest users operate makes for vulnerability in contexts of globalisation and transnational or domestic corporate land deals (Wily 2012), which in turn has prompted calls for greater security of tenure, both by peasant activists and external organisations. At the same time, however, in many countries we have seen in the past few years active developments in national law-making and government regulations aimed at creating a legal framework that will facilitate the corporate acquisition of land held under customary title.

National and local governments and their foreign partners justify the enclosure and corporate appropriation of contested land with the use of an array of discursive tools which on the one hand portray the land as "marginal”, “abandoned”, "barren”, “unused”, "unproductive”, "idle” or even "empty”, and on the other promise a wide range of benefits to local people in the form of infrastructure development and particularly jobs (see the last section of this book, and particularly the chapter by Odoemene in the Nigerian state discourse of the "new Nigeria"). Those who oppose enclosure, using their own discursive tools (Tegomoh, this volume) which we should also analyse critically, can therefore be branded as being "anti-development".

One aspect of contemporary land deals is that they are typically shrouded in secrecy, and with some exceptions (Odoemene, this volume) the agreements or contracts themselves are rarely publicly available. As Lorenzo Cotula observed in a recent report: "Land deal negotiations are unfolding fast and behind closed doors. But secrecy and haste are no friends of good deals" $(2011,3)$. Cotula and his team analyzed the contents of contracts for twelve land deals in seven African countries (Cameroon, Ethiopia, Liberia, Madagascar, Mali, Senegal, and Sudan). These contracts are generally made between host governments and foreign investors, with local landholders or communities, or their representatives, having no formal role at all in the transaction. ${ }^{2}$

A short concrete illustration may help. Bakari Nyari of the Ghanaian NGO RAINS describes how a Norwegian agrofuel company, Agro Fuel Africa (a subsidiary of Bio Fuel Norway), ${ }^{3}$ took advantage of Northern Ghana's traditional system of communal land ownership in an attempt to claim and deforest large tracts of land and create "the largest Jatropha plantation in the world'. Nyari describes how strategies for acquiring land often take the following course:

\footnotetext{
${ }^{2}$ The single exception was Madagascar, where one of the contracts analyzed involved representatives of 13 farmer associations.

${ }^{3}$ www.agrofuel.no
} 
The imaginations of a few influential leaders in the community are captured. They are told about prospects for the community due to the project and they were swayed with promises of positions in the company or with monetary inducements. The idea is that these people do the necessary "footwork" in the villages where they spread the word about job opportunities. A document is then prepared, essentially a contract, to lease the land to the company (Nyari 2008, 3)

The company co-opted local government officials, and together with them persuaded an illiterate local chief to sign away 38,000 ha of land, including several whole villages, with a single thumbprint. To obtain the temporary support of local communities, developers raised local hopes of jobs and income, which did not materialize. As forests were cleared, local people lost their income from forest products, and local leaders (chiefs) were made to appear 'anti-development' when they opposed the project. In this case, however, the opposition, led by RAINS, was able to use Ghana's Environmental Assessment Regulations to get the forest destruction stopped, but not before 2,300 ha of forests had already been stripped. Local women, being those with the most to lose, were the most vocal in opposition. One woman, in a meeting with the company, looked the Agrofuel Africa Chairman Mr. Finn Byberg in the face and asked him:

Look at all the shea nut trees you have cut down already, and consider the fact that the nuts I collect in a year give me cloth for the year and also a little capital. I can invest my petty income in the form of a ram, and sometimes in a good year I can buy a cow. Now you have destroyed the trees and you are promising me something you do not want to commit yourself to. Where then do you want me to go? What do you want me to do? (Nyari 2008, 6)

In this case, Byberg expressed his regrets and a promise not to repeat the mistake. This outcome is indeed unusual, if we recall that many of the agro-industrial groups involved in these deals - both foreign and domestic, usually in some kind of joint-venture arrangement are 'among the most ruthless in the world in terms of environmental destruction, labour conditions and human rights abuses'. 4

\section{How Will Production be Organised? Who Gains, Who Loses?}

Where will the land for these massive deals come from, how will production be organized, and for whose benefit? It is important for critical researchers, besides raising issues of land tenure, to ask further questions about the kinds of structures and labour régimes under which production is or will be organized in the new corporate farms. Under what conditions (whether smallholder contract farming or large plantations using wage labour) are the crops grown and processed? Who among the various actors involved benefits from the value added, generated in field production and the various stages of processing ? And what measures, if

\footnotetext{
${ }^{4}$ As Almuth Ernsting reminds us for Asia (2007, 25).
} 
any, are in place to ensure that smallholder producers, or wage workers, benefit from their involvement?

This links to broader questions that have long been discussed in agrarian studies: why is it that large-scale plantations and areas where smallholder contract-farming is practiced are typically not zones of growing prosperity for ordinary people, but pockets of persistent poverty (Beckford 1972; Little and Watts eds. 1994)? This is not to argue that wage-work in large-scale agriculture, or contract farming for agribusiness, is always impoverishing - why should it be, if labour and farmers are well-organised and their rights, claims and contracts actively promoted and protected by government and the legal system ? But under current conditions, there are grounds for serious concern about the quality of employment in corporate production, for both plantation wage-workers and contracted outgrowers.

These questions can be approached with the same tools of critical analysis that agrarian studies has applied to historical episodes of rapid expansion of large-scale, industrialized, capitalist, monocrop agriculture, in both its plantation and outgrower/contractfarming forms. Henry Bernstein neatly summarizes the research objectives of an agrarian political economy in terms of questions like: "who owns what? who does what? who gets what? what do they do with it?” (Bernstein 2010, 22-24). To these questions we should add: "what do they do to each other?" to capture the relational and political side of property and labour regimes, labour processes and structures of accumulation. A modern and flexible agrarian political economy also incorporates, in its exploration of these questions, dimensions that were relatively neglected in classical agrarian studies, such as the dynamics of gender, ethnicity, livelihood diversity, mobility, rural-urban links, and the environment (White and Dasgupta 2010, 599-600).

\section{Responses and Resistance: Farmers, International Organizations and States}

In many countries, national (state-sponsored) farmers' organisations have not been active in protecting small-farmer and farm-worker rights in the face of large-scale agroindustrial development (in the case of farm-workers' rights on private wildlife farms, see Andrew et al., this volume). Local agrarian movements are more often active, but are themselves weak and sometimes fragmented. In some cases, farmers' organisations and NGOs are themselves split into two camps, one opposing and the other supporting land deals. For those who support the deals, capitalist monocrop farming may not be their chosen vision of the agricultural future, but after decades of state neglect and the failure to provide even the most minimal infrastructure and support to rural areas, it may seem to be the only way in which roads, electricity, schools, health care, and even perhaps some jobs, will come to the communities in question.

Faced with the realities of environmentally and socially irresponsible behaviour of corporate agribusiness, large-scale mining (de Koning, this volume), private wildlife tourism companies (Andrew et al., this volume) and the appropriation of land for conservation purposes ("green grabbing”, see Fairhead, Leach and Scoones 2012), the policy response of international agencies has been to propose the adoption of non-binding rules or principles for responsible corporate behaviour. These include the five-point Code of Conduct proposed by IFPRI experts, The World Bank’s 'Principles for Responsible Agro-investment', or the 
FAO’s ‘Voluntary Guidelines on Responsible Governance of Tenure of Land and Other Natural Resources’ (Von Braun and Meinzen-Dick 2009;

www.responsibleagroinvestment.org; CFS 2012). The World Bank Group’s seven 'Principles for Responsible Agro-Investment', for example, include: respecting land and resource rights; ensuring food security; ensuring transparency, good governance, and a proper enabling environment; consultation and participation; responsible agro-enterprise investing; and social and environmental sustainability.

Two questions should be raised here. First, why should we expect corporations to act on a basis of voluntary corporate 'social responsibility'? The experience of already-existing bodies such as the Round Table on Sustainable Palm Oil and similar set-ups for soya and mining gives no grounds for optimism on the capacity of voluntary guidelines and "codes of conduct" to protect the interests of local cultivators, gender rights, labour and the environment. Years after the establishment of the Round Table, only a tiny fraction of global palm oil production is certified and there is hardly any market for certified palm oil. Capitalist firms are not Boy Scouts, and they are unlikely to place moral codes above the interests and demands of their owners or shareholders (Borras and Franco 2010).

Second, the 'voluntary guidelines' discourse builds on earlier agendas to improve legal and bureaucratic mechanisms for land governance in 'weak' states (World Bank 2010). As I and my LDPI co-authors have argued elsewhere, such portrayals of states as fragile, weak or corrupt and of 'good governance' as a solution to the excesses of expropriation are too facile. They need to be replaced with more nuanced analyses of the ways in which power flows through the various disaggregated levels and functions of the state. States are themselves often active, calculating partners in land deals. While the formal institutions of state and governance are important, they are only one aspect of the multi-faceted relationships which make up states; we need to understand how land deals are shaped by, and shape, the institutions, practices and discourses of territory, sovereignty, authority and subjects (Wolford et al. 2013).

Third, as Olivier De Schutter, the UN Special Rapporteur on the Right to Food, has rightly argued, seeing the solution in terms of such guidelines - designed to mitigate the harm caused to local populations by the expansion of large-scale, capital-intensive farming - is to narrow the terms of the debate, accepting that future agricultural development will be based on large-scale, capital and energy-intensive, agro-industrial monocrop ventures and closing the door to other alternatives, in which small-scale, labour-intensive, environmentally friendly modes of cultivation remain the core units of feeding the planet and keeping it cool. ${ }^{5}$ Professor De Schutter has become the single most important voice within the UN family arguing for a broader vision that 'goes beyond disciplining land deals and providing policymakers with a checklist of how to destroy the global peasantry responsibly' (De Schutter 2011, 275), promoting investment that reduces hunger and malnutrition, rather than aggravating them. In his official reports to the UN General Assembly and Human Rights Council (UN General Assembly 2010a, 2010b), but also in academic publications and numerous keynote addresses, media articles or interviews and press releases, he has taken a

\footnotetext{
${ }^{5}$ On this point, see also Borras \& Franco (2010).
} 
firm stance against the current narrow framing of the debate on 'land grabbing'. He has argued consistently that 'the most pressing issue regarding investment in agriculture is not how much, but how: what we need is not to regulate land grabbing as if this were inevitable, but to put forward an alternative programme for agricultural investment' (2011: 250). In a series of authoritative reports he has argued that alternative approaches must be based not on speculative large-scale acquisitions of farmland, nor on the creation of a market for land rights based on individual titling, but on security of tenure, agrarian reform where land concentration has become excessive, and reorientation of agricultural systems towards agroecological modes of production that are both productive, sustainable and contribute to the progressive realization of the human right to adequate food. De Schutter therefore arrives at a quite different set of 'principles', in which:

Land investments implying an important shift in land rights should represent the last and least desirable option, acceptable only if no other investment model can achieve a similar contribution to local development and improve the livelihoods within the local communities concerned (UN General Assembly 2010a, 20, emphasis added).

\section{Land Deals and Agricultural Futures}

What about the alternatives? The Via Campesina, one of the most successful global networks of small-farmer organisations, campaigns against land grabbing with slogans like:

"Land-grabbing causes hunger! Let small-scale farmers feed the world!” and -

"Small scale sustainable farmers are cooling down the earth"

and therefore demands:

" 1 / The complete dismantling of agribusiness companies: they are stealing the land of small producers, producing junk food and creating environmental disasters.

2/ The replacement of industrialized agriculture and animal production by small-scale sustainable agriculture supported by genuine agrarian reform programmes.”6

Is this romantic nonsense? These claims also need to be critically interrogated. In fact, quite authoritative support on the technical side comes from an important but almost unnoticed international study, the International Assessment of Agricultural Science and Technology for Development (IAASTD 2009). This report was commissioned by a number of UN agencies, including the World Bank and FAO, and drew on the expertise of about 400 specialists from all over the world. It argues that agriculture can and must be reinvented if it is going to feed the world's expanding population sustainably. It concludes that the dominant practice of industrial, large-scale agriculture is unsustainable, mainly because of the dependence of such

\footnotetext{
${ }^{6}$ See various La Via Campesina position papers on http://viacampesina.org
} 
farming on cheap energy, its negative effects on ecosystems, and growing water scarcity. Instead, industrial monocultures must be reconsidered in favour of agro-ecosystems that combine mixed crop production with conserving water supplies, preserving biodiversity, and improving the livelihoods of the poor in small-scale, mixed farming. Although the World Bank was one of the sponsors of this report, the findings are not mentioned in the Bank's (2010) seminal "land grab” report.

There are plenty of opportunities for states, international agencies and even corporate capital to invest in support of this new direction. These do not require the financing of corporate acquisition of land but rather investment in public goods, in rural infrastructure and various forms of support to small-scale agriculture. Farmers themselves still provide the vast bulk of investment in agriculture, dwarfing the expenditures of private foreign investors, governments and international donors. In recent decades, though, governments in the south and the north have placed their focus elsewhere. For the last decade or so, developing country states and the international community have been withdrawing more and more from their role of supporting small farmers and rural development more generally (FAO 2012).

One way to reflect on agricultural futures is to consider what kind of rural future lies ahead for the next generation of rural people. ${ }^{7}$ While some local elders and elites may become rich by facilitating land dispossession and exclusion, and some cultivators may be seduced by, or feel no other option than to accept, immediate cash payments for relinquishing their land, we also need to consider what kind of future these land deals imply for the next generation in rural areas, those who will inherit this future.

Ethnographic studies of "traditional” rural African ways of growing up provide examples in which children and young people who want to farm were allocated a plot of land to farm themselves by parents or other adult relatives or village elders. In Zimbabwe, Elisabeth Colson observed in the 1950s that many Tonga children had their own fields. Unmarried boys or girls might be given a portion of a field belonging to either father or mother before obtaining their own fallowed land, and after harvest might have their own bins in which to store grain from these plots (1960, 79-89). A generation later, in the same region, Pamela Reynolds described how young boys often worked on, and were sometimes allowed to make, their own farms on the land of a parent or other relative, and thus 'actively direct their labour contributions in accord with various strategies that maximize their chances of meeting current needs, and establishing links among kin and neighbours that will enhance future security' (1991, xxvii). But in how many countries and regions is it still possible for young people to slip themselves into independent agricultural production and earning in the way that these examples have shown? One reason why young people express a reluctance to farm may reflect not an aversion to farming as such, but to the long period of waiting that they would have to face before they have a chance to engage in independent farming.

Recent generations of young men and women are often confronted by the narrowing and sometimes complete closure of opportunities to gain access to a plot of land. Buchalik (this volume) describes how the generational transfer of farm land among the Voltaic peoples in Burkina Faso has undergone organic transformation in the face of construction of a

\footnotetext{
${ }^{7}$ The ideas in the final part of this chapter on implications for the next generation are discussed in greater detail in White (2012).
} 
national road network. This blocking or postponement of generational transfers may happen under all kinds of land tenure systems, whether land is held in private title, under customary tenure (in which use rights to farm plots are allocated by family or clan elders or chiefs) or as 'state lands'. Meanwhile the expansion of formal education and particularly secondary education contributes to a process of de-skilling of rural youth in which farming skills are neglected and farming is downgraded as an occupation, as Katz (2004, 143-151) has noted in Sudan. Young people are already moving to the cities in large numbers, and it is now widely assumed that young rural people are uninterested in agricultural futures,

Arguments for smallholder-based alternatives and against large-scale, capital- and energy-intensive corporate farming lose some of their cogency if the next generation of young men and women are genuinely not interested in farming . But this should not be taken for granted. Julian Quan summarising studies from various African countries observes

... limitations in young people's access to land, land concentration, and land sales and allocations outside the kin group by older generations can become highly problematic where alternative livelihoods are not available, and can trigger wide social conflicts (Quan 2007, 57)

Georges Kouamé (2010) describes such conflicts from Côte d'Ivoire, where Abure youth, angered at the way the old men preferred to rent the land out to Burkinabe migrants for pineapple cultivation rather than letting their own young people work it, destroyed the pineapple crops in the field.

Among the few scholars who have been arguing consistently for the need to find ways to make farming a better and more available option for young people are Paul Richards and his former student, Krijn Peters. Peters describes in detail the mismanagement and stagnation of the agricultural sector in conflict-torn regions of Sierra Leone, the false hope that education gave young people of recognition and success, and the vulnerability of young people to local seniors which was evident in the elders' control over customary courts, land, agricultural labour, and the allocation of marriage partners.

The point is that the African rural setting is not only inhabited by landowning peasants, but increasingly by numbers of young people who lack the basic modalities even to be peasants [...] They cannot even mobilize their own labour to work the allegedly abundant land, since this would be vulnerable to extraction from them by marriage payments and court fines for infringements of a traditional code of behaviour regulated by elders. (2011, 224f.)

Peters argues that 'the dislike of rural youth [for agriculture] is not focused on agriculture as such, but on their vulnerability, in village conditions, to exploitation by local elites and gerontocrats' (2011, 203). Reviewing recent proposals for (bio)technical solutions to African agrarian poverty, Richards concludes '....perhaps an even bigger focus for reform [than biotechnology] is the need to open up land to more intensive use by making it more readily accessible to young people, free from control by a local gerontocratic order' $(2010,560)$. 
The issue of intergenerational transfer of land rights - or, when that does not happen, intergenerational dispossession when one generation's land is sold off which ought to have been passed on to the next - deserves our attention. If we are interested in small-farm based alternatives to industrial capitalist agriculture, there needs to be a generation of rural men and women interested to take up the challenge.

As I have tried to indicate, and as further chapters in this volume demonstrate, the current debate about "land grabbing" is in fact a debate about the future shape of farming and the fate of rural populations. There are real and important choices to be made, with important consequences for the coming generations. We might express them in this way: will young men and women still have the option, and the necessary support, to engage in environmentally sound, small scale, commercial mixed farming, providing food and other needs for their own society and others? Or will they only face the choice to become poorlypaid wage workers or impoverished contract farmers, in an endless landscape of monocrop food or fuel feedstock plantations, on land which used to belong to their parents, or to move to an uncertain existence in the informal sector of already crowded cities?

\section{BIBLIOGRAPHY}

Anseeuw, Ward, Liz Alden Wily, Lorenzo Cotula, and Michael Taylor. Land Rights and the Rush for Land: Findings of the Global Commercial Pressures on Land Research Project. Rome: International Land Coalition, 2012

Beckford, George. Persistent Poverty: Underdevelopment in the Plantation Economies of the Third World. New York: Oxford University Press, 1972.

Bernstein, Henry. Class Analysis of Agrarian Change. Halifax and Sterling: Fernwood Publishing and Kumarian Press, 2010.

Borras, Saturnino Jr. \& Jennifer Franco. "From Threat to Opportunity? Problems with the Idea of a 'Code of Conduct' for Land-Grabbing”. Yale Human Rights \& Development Law Journal 13 (2010): 507-523.

Von Braun, Joachim and Ruth Meinzen-Dick. “ 'Land grabbing' by foreign investors in developing countries - risks and opportunities”. Policy Brief No. 13. Washington: IFPRI, 2009.

CFS. Voluntary Guidelines on the R esponsib le $G$ ovemance of T enure of $L$ and, $F$ isheries and Forests in the Context of National Food Security. Final version, March 2012. Rome: FAO Committee on World Food Security.

http://www.csm4cfs.org/files/2/vg_en_final_march_2012.pdf, accessed 12 July 2012.

Colson, Elizabeth. Social Organization of the Gwemba Tonga, Manchester: Manchester University Press, 1960.

Cotula, Lorenzo . Land Deals in Africa: What is in the Contracts? London: International Institute of Environment and Development, 2011.

Cotula, Lorenzo. "The international political economy of the global land rush: a critical appraisal of trends, scale, geography and drivers”, The Journal of Peasant Studies 39 (3-4), pp. 649-680, 2012

De Schutter, Olivier. "How not to think of land-grabbing : three critiques of large-scale investments in farmland”, The Journal of Peasant Studies 38, 2 (2011), pp. 249-79. 
Ernsting, Almuth. “Agrofuels in Asia: fuelling poverty, conflict, deforestation and climate change”. Seedling (July): 25-33, 2007,

Fairhead, James, Melissa Leach and Ian Scoones. "Green grabbing: a new appropriation of nature?” The Journal of Peasant Studies 39 (2), pp. 237-261, 2012.

FAO. The State of Food and Agriculture 2012: Investing in Agriculture for a Better Future. Rome: Food and Agriculture Organization of the Un ited Nations, 2012.

Hall, Ruth. "Land Grabbing in Southern Africa: The Many Faces of the Investor Rush”. Review of African Political Economy 128, 193-214, 2011.

IAASTD. Synthesis Report: Agriculture at a Crossroads: International Assessment of Agricultural Science and Technology for Development. Washington: Island Press, 2009.

Kalecki, Michal. "Social and economic aspects of 'intermediate regimes' " in M. Kalecki, Selected Essays on the Economic Growth of the Socialist and the Mixed Economy. Cambridge: University Press, 162-169, 1972 (orig. 1967).

Katz, Cindi. Growing up Global: Economic Restructuring and Children"s Everyday Lives. Minneapolis: University of Minnesota Press, 2004.

Kouamé, Georges "Intra-family and socio-political dimensions of land markets and land conflicts: the case of the Abure, Côte d'Ivoire”, Africa: The Journal of the International African Institute, 80, 1 (2010): 126-146.

Lipton, Michael. Land Reform in Developing Countries: Property Rights and Property Wrongs. London and New York: Routledge, 2010.

Little, Peter and Michael Watts eds. Living Under Contract: Contract Farming and Agrarian Transformation in Sub-Saharan Africa. Madison: University of Wisconsin Press, 1994.

Nyari, Bakari “Biofuel land grabbing in Northern Ghana”, 2008 http://www.biofuelwatch.org.uk/files/biofuels_ghana.pdf

Oxfam. Land and Power: The Growing Scandal Surrounding the New Wave of Investments in Land. Oxfam Briefing Paper 151. Oxford: Oxfam GB for Oxfam International, 2011.

Quan, Julian. "Changes in intra-family relations” in L. Cotula ed., Changes in "Customary” Land Tenure Systems in Africa, 51-63. London: IIED/FAO, 2007.

Peters, Krijn. War and the Crisis of Youth in Sierra Leone. Cambridge: University Press, 2011.

Reynolds, Pamela. Dance Civet Cat: Child Labour in the Zambezi Valley. London: Zed Books, 1991.

Richards, Paul. “ Do peasants need GM crops?” Journal of Peasant Studies 37, 3 (2010): 559-574.

Scoones, Ian. Investing in land: a commentary on the World Bank report. News item, www.future-agricultures.org,16 September 2010.

Sobhan, Rehman . Agrarian Reform and Social Transformation. London: Zed Books, 1993.

UN General Assembly. Report of the Special Rapporteur on the Right to Food. New York: UN General Assembly, 65 ${ }^{\text {th }}$ session, August (2010a).

UN General Assembly. Report submitted by the Special Rapporteur on the Right to Food. New York: UN General Assembly, Human Rights Council, $16^{\text {th }}$ session, December (2010b).

Warriner, Doreen . Land Reform in Principle and Practice. Oxford: Clarendon Press, 1969. 
White, Ben. "Who will own the countryside? Dispossession, rural youth and the future of farming". Valedictory Address delivered on the $59^{\text {th }}$ Dies Natalis of the International Institute of Social Studies. The Hague: International Institute of Social Studies, 13 October 2011.

White, Ben. "Agriculture and the generation problem: rural youth, employment and the future of farming”, IDS Bulletin 43 (6), pp. 9-19, 2012

White, Ben and Anirban Dasgupta. "Agrofuels capitalism: a view from political economy” the Journal of Peasant Studies 37, 4, pp. 593-607, 2010

Wily, Liz Alden "Looking back to see forward: the legal niceties of land theft in land rushes”, The Journal of Peasant Studies 39 (3-4), pp. 751-775, 2012.

Wolford, Wendy, Saturnino M. Borras Jr., Ruth Hall, Ian Scoones and Ben White. "Governing global land deals: the role of the state in the rush for land", Development and Change 44 (2), (in press, March 2013).

World Bank. Rising Global Interest in Farmland: Can it Yield Equitable and Sustainable Benefits ? Washington DC: The World Bank, 2010.

Zoomers, Annelies. "Globalisation and the foreignisation of space: seven processes driving the current global land grab” Journal of Peasant Studies 37, 2 (2010) : 429-447.

Ben White is Emeritus Professor of Rural Sociology at the Institute of Social studies, The Hague. He has been involved in teaching and research on agrarian and rural development issues for more than 40 years, with a research focus primarily on Indonesia. He has published many books and articles on agrarian history, land tenure, rural poverty, contract farming and the rural non-farm economy. A second area of interest is the anthropology and history of childhood and youth. 